\title{
Björk-Jarabak cephalometric analysis on CBCT synthesized cephalograms with different dentofacial sagittal skeletal patterns
}

\author{
Yalil Augusto Rodriguez-Cardenas'1, Luis Ernesto Arriola-Guillen², Carlos Flores-Mir ${ }^{3}$
}

DOI: http://dx.doi.org/10.1590/2176-9451.19.6.046-053.oar

Objective: The objective of this study was to evaluate the Björk and Jabarak cephalometric analysis generated from cone-beam computed tomography (CBCT) synthesized lateral cephalograms in adults with different sagittal skeletal patterns. Methods: The sample consisted of 46 CBCT synthesized cephalograms obtained from patients between 16 and 40 years old. A Björk and Jarabak cephalometric analysis among different sagittal skeletal classes was performed. Analysis of variance (ANOVA), multiple range test of Tukey, Kruskal-Wallis test, and independent t-test were used as appropriate. Results: In comparison to the standard values: Skeletal Class III had increased gonial and superior gonial angles $(\mathrm{P}<0.001)$. This trend was also evident when sex was considered. For Class I males, the sella angle was decreased $(\mathrm{P}=0.041)$, articular angle increased $(\mathrm{P}=0.027)$ and gonial angle decreased $(\mathrm{P}=0.002)$; whereas for Class III males, the gonial angle was increased $(\mathrm{P}=0.012)$. For Class I females, the articular angle was increased $(\mathrm{P}=0.029)$ and the gonial angle decreased $(\mathrm{P}=0.004)$. Björk's sum and Björk and Jabarak polygon sum showed no significant differences. The facial biotype presented in the three sagittal classes was mainly hypodivergent and neutral. Conclusions: In this sample, skeletal Class III malocclusion was strongly differentiated from the other sagittal classes, specifically in the mandible, as calculated through Björk and Jarabak analysis.

Keywords: Cephalometry. Computed tomography scanners. Malocclusion.

Objetivo: o objetivo deste estudo foi avaliar a análise cefalométrica de Björk-Jarabak realizada com base em telerradiografias sintetizadas a partir de tomografia computadorizada de feixe cônico (TCFC) em adultos com diferentes padrões esqueléticos sagitais. Métodos: a amostra foi composta de 46 telerradiografias sintetizadas a partir de TCFC obtidas de pacientes entre 16 e 40 anos de idade. A análise cefalométrica de Björk-Jarabak foi conduzida entre as diferentes classes esqueléticas sagitais. Análise de variância (ANOVA), teste de Tukey, de Kruskal-Wallis e teste $t$ independente também foram realizados. Resultados: em comparação a valores padrão, a má oclusão de Classe III esquelética apresentava ângulos goníacos aumentados $(\mathrm{p}<0,001)$. Essa tendência também foi evidente quando o sexo dos pacientes foi considerado. Pacientes Classe I do sexo masculino tiveram o ângulo sela diminuído $(\mathrm{p}=0,041)$, o ângulo articular aumentado $(\mathrm{p}=$ $0,027)$ e o ângulo goníaco também diminuído $(\mathrm{p}=0,002)$. Já os pacientes Classe III tiveram o ângulo goníaco aumentado $(\mathrm{p}=0,012)$. Pacientes Classe I do sexo feminino tiveram o ângulo articular aumentado $(p=0,029)$ e o ângulo goníaco diminuído $(\mathrm{p}=0,004)$. A soma de Björk e a soma dos polígonos de Björk-Jarabak não revelaram diferenças significativas. O biótipo facial presente nas três classes sagitais foi hipodivergente e neutro. Conclusões: na amostra do presente estudo, a má oclusão esquelética de Classe III foi fortemente diferenciada de outras classes sagitais, principalmente na mandíbula, conforme demonstrado pela análise de Björk-Jarabak.

Palavras-chave: Cefalometria. Tomógrafo. Má oclusão.

" Patients displayed in this article previously approved the use of their facial and intraoral photographs.

${ }^{1}$ Specialist in Orthodontics, National University of Colombia. Specialist in Oral and Maxillofacial Radiology, Universidad Peruana Cayetano Heredia.

${ }^{2}$ Associate Professor, Department of Orthodontics, School of Dentistry, Universidad Científica del Sur-UCSUR and Universidad Nacional Mayor de San Marcos, UNMSM.

${ }^{3}$ Associate Professor and Head of the Department of Orthodontics, University of Alberta.
How to cite this article: Rodriguez-Cardenas YA, Arriola-Guillen LE, FloresMir C. Björk-Jarabak cephalometric analysis on CBCT synthesized cephalograms with different dentofacial sagittal skeletal patterns. Dental Press J Orthod. 2014 Nov-Dec;19(6):46-53. OI: http://dx.doi.org/10.1590/2176-9451.19.6.046-053.oar

Submitted: July 27, 2013 - Revised and accepted: February 07, 2014

" The authors report no commercial, proprietary or financial interest in the products or companies described in this article.

Contact address: Yalil Augusto Rodríguez-Cárdenas

Carrera 17 \# 15 - 08 Of 201 - Duitama, Colombia

E-mail: yalilrodriguez@gmail.com 


\section{INTRODUCTION}

The recent development of cone-beam computed tomography (CBCT) for craniofacial imaging has encouraged its use in Orthodontics by providing volumetric information that allows the development of three-dimensional models valuable for impacted teeth localization, TMJ visualization, among other applications. ${ }^{1,2,3}$ It has also allowed the production of $2 \mathrm{D}$ high resolution imaging without magnification. ${ }^{4}$ This latter aspect facilitates the use of CBCT synthesized cephalograms for orthodontic treatment planning. In this regard, three methods to simulate conventional two-dimensional cephalograms from CBCT images and volumetric data sets have been described: ${ }^{5}$ Lateral scout radiograph taken initially to confirm patient's positioning, maximum intensity projection (MIP), and ray-sum technique.

Replacement of conventional 2D radiographs by their 3D counterpart appears to be a trend. ${ }^{7}$ $3 \mathrm{D}$ volumetric imaging of the maxilla and mandible has been studied in various skeletal classifications. ${ }^{8}$ Moreover, no statistical differences between cephalometric analyses performed on conventional and CBCT-generated cephalograms of patients has been shown several times. ${ }^{9,11,12}$

CBCT-synthesized cephalograms have been used to perform cephalometric analyses, comparing the three types of 2D images that can be produced (conventional, ray-sum, or MIP). ${ }^{9}$ However, other authors have found better accuracy on ray-sum produced images, and reported it as a potential method to better simulate lateral cephalometric images from CBCT data sets. ${ }^{10}$ The latter is described in more detail in a previous study. ${ }^{6}$ In summary, the produced images can be thickened by increasing the number of adjacent voxels. This summation process is called "ray-sum", and can create an image that represents a specifically defined volume of the patient. By adding the intensity values of adjacent voxels along a particular section, its thickness increases and creates a thin plate of 5 to $10 \mathrm{~mm}$, or thicker (more than $20 \mathrm{~mm}$ if desired), allowing the production of flat cephalograms without distortion, which can be exported and analyzed by means of cephalometric analysis programs.

Jarabak's cephalometric analysis, ${ }^{13}$ based on a study by Björk, ${ }^{14}$ has been used to compare facial variations of shape and size based on age, sex and race. Jarabak's cephalometric analysis mainly considers vertical intermaxillary relationships and uses the cranial base as reference. The final response of Jarabak's polygon to different sagittal skeletal malocclusions, including facial biotypes as shown in non-growing young adults, is an issue that has not been studied yet. The purpose of this study is, therefore, to evaluate Björk and Jabarak cephalometric analysis on CBCT-generated cephalograms with different dentofacial sagittal skeletal patterns.

\section{METHODS}

The study was approved by local ethics committee. CBCT-synthesized lateral cephalograms from 46 subjects (24 men, 22 women) were randomly selected from an available database (Table 1). Sample size was calculated considering a gonial angle difference ${ }^{15}$ of $3^{\circ}$ between Class I and III malocclusion as clinically relevant, with an expected variance of $9^{\circ}$. With a onesided significance level of 0.05 and a power of $80 \%$, a minimum of 12 patients per group was required.

The final number of participants included was of 46 (15 for Class I, 15 for Class II, and 16 for Class III malocclusion subjects). Inclusion criteria were: CBCT with large field of view (FOV), and patients aged between 16 and 40 years (all subjects had complete craniofacial growth as determined by CVM 6). ${ }^{16}$ Participants were in centric occlusion (maximum intercuspidation) during CBCT imaging, and no chin positioner was used to avoid possible alterations in jaw position. Exclusion criteria were: Patients with severe asymmetries, known craniofacial syndromes, under active orthodontic

Table 1 - Descriptive statistics of the sample by skeletal class and sex

\begin{tabular}{ccccc}
\hline $\begin{array}{c}\text { Skeletal } \\
\text { Class }\end{array}$ & Sex & n & ANB & FMA \\
\multirow{2}{*}{ Class I } & Male & 8 & 3.19 & 25.74 \\
& Female & 7 & 2.86 & 27.46 \\
\multirow{2}{*}{ Class II } & Male & 8 & 7.12 & 31.01 \\
& Female & 7 & 7.84 & 32.00 \\
\multirow{2}{*}{ Class III } & Male & 8 & -4.04 & 32.02 \\
& Female & 8 & -4.58 & 27.07 \\
\hline
\end{tabular}


treatment, with tooth loss (except for third molars) or with prior history of orthognatic surgery.

Imaging was performed with a Picasso Master 3D (Vatech, E-WOO Technology Co, Ltd, Republic of Korea). Device settings were set at $8 \mathrm{~mA}$ and $90 \mathrm{kV}$. Each field of view mode was $20 \mathrm{~cm}$ X $19 \mathrm{~cm}$. The image was processed with EZImplant 3D software which allowed the generation of ray-sum type generated 2D lateral skull projection cephalometrics (Fig 1).

\section{Cephalometric analysis}

The cephalometric analysis was derived from Björk and Jarabak analysis ${ }^{13}$ (Fig 2) and included: N-S-Ar (saddle angle), S-Ar-Go (articular angle), Ar-Go-Me (gonial angle), Ar-Go-N (upper gonial angle), N-Go-Me (lower gonial angle) plus the following linear measurements: S-Go (posterior facial height), and N-Me (anterior facial height) (Fig 1).

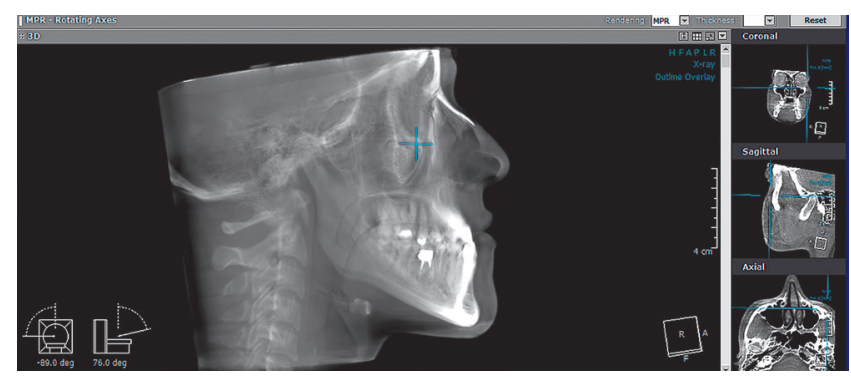

Figure 1 - Example of CBCT cephalogram used in this study.

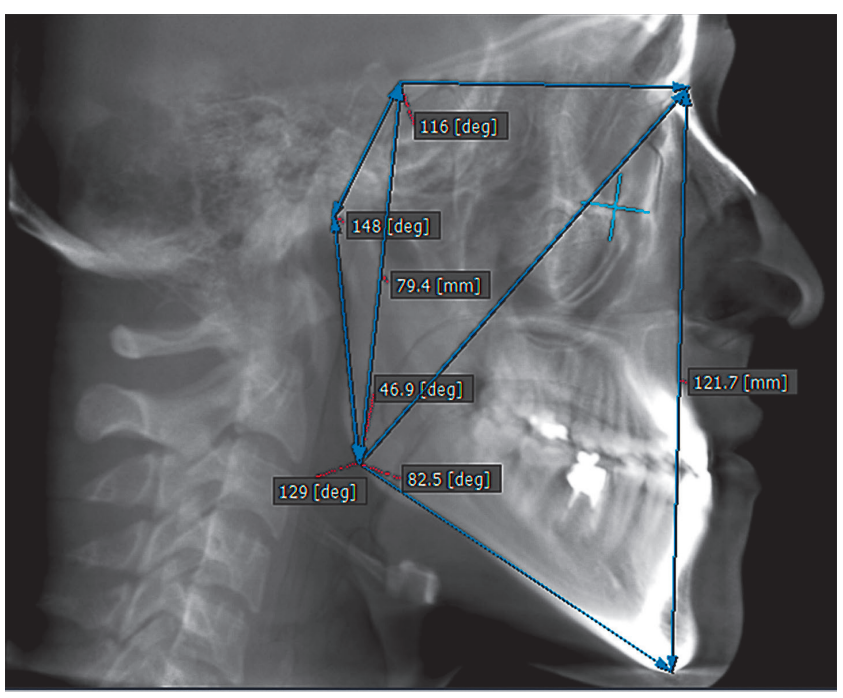

Figure 2 - Angular and linear parameters for Björk and Jarabak analysis used in this study.
Additionally, ANB angle was determined and analyzed for each participant. Participants were classified into three groups according to skeletal pattern: Skeletal Class I $\left(0^{\circ} \leq \mathrm{ANB}<4^{\circ}\right)$, Class II $\left(\mathrm{ANB} \geq 4^{\circ}\right)$, and Class III $\left(\mathrm{ANB}<0^{\circ}\right)$. The definitions of points and angles used in this study were according to those described by Northway et al. ${ }^{17}$

\section{Methods for error analysis}

Cephalometric tracings were performed by an orthodontist previously calibrated for the Björk and Jarabak analysis and with 10 years of experience drawing cephalograms. Intraexaminer reliability was assessed with the intraclass correlation coefficient (ICC) which gave a result greater than 0.90 for all measurements (confidence intervals between $0.900-0.999)$. In addition, Dahlberg error was less than $1^{\circ}(0.25$ to 0.99$)$ in angular measurements and less than $0.8 \mathrm{~mm}$ (0.5 to 0.8 ) in linear measurements. All cephalometric tracings were drawn twice with a one-week interval in between.

\section{Statistical analysis}

All statistical analyses were performed using SPSS v.19 for Windows (IBM SPSS, Chicago, Illinois, USA). Normal distribution was confirmed by Shapiro-Wilk tests. One-way analysis of variance (ANOVA) was performed to determine whether there were differences in angles across the sagittal malocclusion types, if normality and homogeneity of variance assumptions were satisfied; otherwise, the equivalent non-parametric Kruskal-Wallis test was used. In addition, analysis of variance (ANOVA) was performed to take into account the significant differences between males and females in terms of sagittal skeletal patterns. The post-hoc analysis was a Tukey HSD. For comparisons between sex, angular measurements and comparisons of Björk and Jarabak analysis, an independent t-test was used. Statistical significance was set at $\mathrm{P}<0.05$ for all tests.

\section{RESULTS}

Descriptive statistics for ANB angle, FMA angle, sex and the number of patients for each sagittal skeletal class are shown in Table 1. Class III skeletal had increased gonial and superior gonial angles $(\mathrm{P}<0.001)$ during intergroup analysis (Table 2$)$. 
Table 2 - Evaluation of cephalometric Björk and Jarabak's measurements according to sagittal skeletal class.

\begin{tabular}{|c|c|c|c|c|c|c|c|c|}
\hline $\begin{array}{l}\text { Skeletal } \\
\text { class }\end{array}$ & $\begin{array}{l}\text { Cephalometric } \\
\text { measurements }\end{array}$ & $\mathrm{x}$ & SD & Min & $\operatorname{Max}$ & $\mathrm{S}^{2}$ & $p(1,2,3)$ & Multiple comparison (p) \\
\hline \multirow{7}{*}{ 1. Class I } & NSAr & 122.27 & 6.32 & 114.00 & 134.00 & 39.92 & $0.07^{\star \star \star}$ & \multirow{21}{*}{$\begin{array}{l}(I, I I I p=<0.001)(I I, I I I p=0.018)^{\star \star * *} \\
(I, I I I p=0.001)(I I, I I \mid p=0.009)^{\star * *}\end{array}$} \\
\hline & SArGo & 148.27 & 8.81 & 132.00 & 161.00 & 77.64 & $0.054^{*}$ & \\
\hline & ArGoMe & 122.87 & 4.05 & 117.00 & 129.00 & 16.41 & $0.001^{*}$ & \\
\hline & ArGoN & 43.32 & 7.84 & 30.70 & 57.60 & 61.49 & $0.001^{*}$ & \\
\hline & MeGoN & 76.48 & 4.89 & 65.20 & 83.30 & 23.87 & $0.124^{* \star}$ & \\
\hline & NMe & 118.85 & 6.99 & 106.90 & 132.90 & 48.91 & $0.928^{* \star}$ & \\
\hline & SGo & 80.99 & 5.47 & 72.70 & 91.50 & 29.97 & $0.152^{*}$ & \\
\hline \multirow{7}{*}{ 2. Class II } & NSAr & 122.73 & 7.51 & 102.00 & 135.00 & \multicolumn{2}{|l|}{56.35} & \\
\hline & SArGo & 149.20 & 8.92 & 138.00 & 167.00 & \multicolumn{2}{|l|}{79.60} & \\
\hline & ArGoMe & 125.93 & 6.15 & 116.00 & 139.00 & \multicolumn{2}{|l|}{37.78} & \\
\hline & ArGoN & 44.73 & 5.71 & 34.90 & 53.20 & \multicolumn{2}{|l|}{32.56} & \\
\hline & MeGoN & 79.32 & 6.49 & 72.60 & 91.30 & \multicolumn{2}{|l|}{42.08} & \\
\hline & NMe & 119.39 & 6.74 & 105.70 & 127.90 & \multicolumn{2}{|l|}{45.42} & \\
\hline & SGo & 78.35 & 4.59 & 72.10 & 88.40 & \multicolumn{2}{|l|}{21.10} & \\
\hline \multirow{7}{*}{ 3. Class III } & NSAr & 121.63 & 6.02 & 113.00 & 133.00 & \multicolumn{2}{|l|}{36.25} & \\
\hline & SArGo & 142.31 & 7.29 & 129.00 & 154.00 & \multicolumn{2}{|l|}{53.16} & \\
\hline & ArGoMe & 132.81 & 8.89 & 119.00 & 146.00 & \multicolumn{2}{|l|}{79.10} & \\
\hline & $\operatorname{ArGoN}$ & 51.32 & 3.49 & 43.30 & 56.60 & \multicolumn{2}{|l|}{12.20} & \\
\hline & MeGoN & 81.89 & 6.20 & 74.00 & 92.50 & \multicolumn{2}{|l|}{38.47} & \\
\hline & NMe & 120.09 & 9.36 & 109.20 & 135.00 & \multicolumn{2}{|l|}{87.55} & \\
\hline & SGO & 76.84 & 7.18 & 66.00 & 88.90 & \multicolumn{2}{|l|}{51.54} & \\
\hline
\end{tabular}

*ANOVA. ** Kruskal-Wallis. *** Tukey.

Table 3 - Comparison between the studied sella, articular and gonial angles and the Björk and Jabarak standard by skeletal class and sex.

\begin{tabular}{|c|c|c|c|c|c|c|c|c|c|}
\hline \multirow{2}{*}{ Skeletal class } & \multirow{2}{*}{$\operatorname{Sex}$} & \multirow{2}{*}{ Angle } & \multirow{2}{*}{ SD } & \multirow{2}{*}{ Standard } & \multirow{2}{*}{ SD } & \multirow{2}{*}{$\mathbf{p}$} & \multirow{2}{*}{ Mean difference } & \multicolumn{2}{|c|}{$95 \%$ confidence interval } \\
\hline & & & & & & & & Lower & Upper \\
\hline \multicolumn{10}{|c|}{ Sella angle } \\
\hline \multirow{2}{*}{ Class 1} & Male & 118.50 & 4.50 & 123 & 5 & 0.041 & -4.42 & -8.9 & -0.26 \\
\hline & Female & 125.50 & 6.07 & 123 & 5 & 0.282 & 2.50 & -2.58 & 7.58 \\
\hline \multirow{2}{*}{ Class II } & Male & 123.10 & 11.02 & 123 & 5 & 0.974 & 0.14 & -10.05 & 10.34 \\
\hline & Female & 122.37 & 2.87 & 123 & 5 & 0.558 & -0.62 & -3.03 & 1.78 \\
\hline \multirow{2}{*}{ Class III } & Male & 121.80 & 4.54 & 123 & 5 & 0.507 & -1.12 & -4.93 & 2.68 \\
\hline & Female & 121.30 & 7.53 & 123 & 5 & 0.561 & -1.62 & -7.93 & 4.68 \\
\hline \multicolumn{10}{|c|}{ Articular angle } \\
\hline \multirow{2}{*}{ Class 1} & Male & 151.40 & 7.63 & 143 & 6 & 0.027 & 8.42 & 1.37 & 15.49 \\
\hline & Female & 145.50 & 9.30 & 143 & 6 & 0.472 & 2.50 & -5.28 & 10.28 \\
\hline \multirow{2}{*}{ Class $\|$} & Male & 147.10 & 9.82 & 143 & 6 & 0.307 & 4.14 & -4.94 & 13.23 \\
\hline & Female & 151.00 & 8.28 & 143 & 6 & 0.029 & 8.00 & 1.08 & 14.92 \\
\hline \multirow{2}{*}{ Class III } & Male & 137.80 & 6.89 & 143 & 6 & 0.074 & -5.12 & -10.89 & 0.64 \\
\hline & Female & 146.70 & 4.62 & 143 & 6 & 0.055 & 3.75 & -0.11 & 7.61 \\
\hline \multicolumn{10}{|c|}{ Gonial angle } \\
\hline \multirow{2}{*}{ Class I } & Male & 122.80 & 3.48 & 130 & 7 & 0.002 & -7.14 & -10.37 & -3.92 \\
\hline & Female & 122.80 & 4.73 & 130 & 7 & 0.004 & -7.12 & -11.08 & -3.17 \\
\hline \multirow{2}{*}{ Class II } & Male & 125.80 & 7.69 & 130 & 7 & 0.204 & -4.14 & -11.26 & 2.97 \\
\hline & Female & 126.00 & 4.98 & 130 & 7 & 0.058 & -4.00 & -8.17 & 0.17 \\
\hline \multirow{2}{*}{ Class III } & Male & 138.80 & 7.51 & 130 & 7 & 0.012 & 8.87 & 2.60 & 15.15 \\
\hline & Female & 126.70 & 5.39 & 130 & 7 & 0.132 & -3.25 & -7.76 & 1.26 \\
\hline
\end{tabular}

Independent t-test. 
Table 4 - Comparison between the sum (Björk) studied and the standard by skeletal class and sex.

\begin{tabular}{|c|c|c|c|c|c|c|c|c|c|}
\hline \multirow{2}{*}{ Skeletal class } & \multirow{2}{*}{$\operatorname{Sex}$} & \multirow{2}{*}{$\begin{array}{c}\text { Sum (Björk) } \\
\text { Studied }\end{array}$} & \multirow{2}{*}{ SD } & \multirow{2}{*}{$\begin{array}{l}\text { Sum (Björk) } \\
\text { Standard }\end{array}$} & \multirow{2}{*}{ SD } & \multirow{2}{*}{ p } & \multirow{2}{*}{ Mean difference } & \multicolumn{2}{|c|}{$95 \%$ confidence interval } \\
\hline & & & & & & & & Lower & Upper \\
\hline \multirow{2}{*}{ Class I } & Male & 392.70 & 5.20 & 396 & 6 & 0.074 & -3.14 & -6.70 & 0.42 \\
\hline & Female & 393.80 & 6.70 & 396 & 6 & 0.263 & -2.12 & -6.26 & 2.01 \\
\hline \multirow{2}{*}{ Class $\|$} & Male & 396.00 & 9.51 & 396 & 6 & 0.331 & 0.14 & -6.05 & 6.33 \\
\hline & Female & 399.00 & 5.37 & 396 & 6 & 0.957 & 3.37 & -4.26 & 11.01 \\
\hline \multirow{2}{*}{ Class III } & Male & 398.40 & 4.80 & 396 & 6 & 0.274 & 2.62 & -2.60 & 7.85 \\
\hline & Female & 394.70 & 5.84 & 396 & 6 & 0.309 & -1.12 & -3.55 & 1.30 \\
\hline
\end{tabular}

Independent t-test

Table 5 - Characteristics of Björk and Jabarak facial height ratio by sex and skeletal class.

\begin{tabular}{ccccc}
\hline Class & Female & Facial type & Male & Facial type \\
\hline I & $67.30^{\circ}$ & CCW - HIPO & $69.04^{\circ}$ & CCW-HIPO \\
II & $64.62^{\circ}$ & NEUTRO & $66.74^{\circ}$ & CCW - HIPO \\
III & $63.62^{\circ}$ & NEUTRO & $64.28^{\circ}$ & NEUTRO \\
\hline
\end{tabular}

CCW-HYPO: Counterclockwise rotation hypodivergent.

In comparison to published standards:

For Class I males, the sella angle was decreased $(\mathrm{P}=0.041)$, articular angle increased $(\mathrm{P}=0.027)$ and gonial angle decreased $(\mathrm{P}=0.002)$; whereas for Class III males, the gonial angle was increased $(\mathrm{P}=0.012)$. For Class I females, the articular angle was increased $(\mathrm{P}=0.029)$ and the gonial angle decreased $(\mathrm{P}=0.004)$ (Table 3$)$.

Björk's sum and Björk and Jabarak polygon sum showed no significant differences among the different sagittal patterns. (Table 4)

For this sample, the facial biotype presented in the three sagittal classes was mainly hypodivergent and neutral (Table 5).

\section{DISCUSSION}

Lateral cephalometric analyses have been extensively used to develop guidelines that aid in orthodontic diagnosis and treatment planning. CBCT images allow clinicians to reformat volumetric 3D data set to conventional 2D by simulating plane projections such as a synthesized lateral cephalometric view. Several studies have been conducted to assess the accuracy of cephalometric measurements using CBCT images; ${ }^{18,19}$ however, no previous study has analyzed Björk and Jarabak's cephalometric analysis in a young adult non-growing population. The sample of this study comprised non-growing patients, which was confirmed by Bacceti's analysis, revealing that all patients were on CS6. Thus, age was not a variable and there was no bias. Björk and Jabarak analysis provides extensive information about the facial biotype of a patient through only a few cephalometric measurements. Previous researchers have emphasized the need to expand available norms for adult populations..$^{20,21,22}$

A few published studies have specifically used significant parts or all of Björk and Jabarak analysis. All of them were conducted only on growing individuals with different facial biotypes. Chung et $\mathrm{al}^{23}$ reported the longitudinal craniofacial growth changes in untreated skeletal Class I subjects with low, average, and high MP-SN angles. They found that the SNA and SNB angles increased with age in all groups. Moreover, Alexander et $\mathrm{al}^{24}$ reported cephalometric growth changes in untreated Class III malocclusions by using semi-longitudinal cephalometric records. They found that the length of the anterior skull base increases with age less than $1 \mathrm{~mm}$ per year for women and around $1 \mathrm{~mm}$ for men. This increase is similar to Class I subjects; however, the longitudinal nature of this study is not accurate, because the sample comparisons between age groups were not performed on the same initial study group.

Reyes et $\mathrm{l}^{25}$ provided an estimate of facial growth in Class III malocclusion and found that the sella angle is smaller in Class III than in subjects with normal occlusion in both males and females. A report by Kuramae et $\mathrm{al}^{26}$ found that cephalometric measurements calculated for black Brazilian patients were similar to Jarabak's standards, except for S-N mean value for female patients, which was significantly lower than the established Jarabak's standard. The application of Björk and Jarabak analysis in all 
mentioned studies reinforces its relevance in the current context of orthodontic diagnosis, but no reports highlight findings on an adult population.

Because subjects at the same chronological age may have different skeletal maturation levels, evaluation of non-growing subjects may be important to determine specific characteristics of a given skeletal class. Dibbets ${ }^{27}$ stated that differences in mandibular size between Angle classes emerge later during development, and therefore, these differences are more likely to be found in adult samples. Kerr and Hirst, ${ }^{28}$ in a longitudinal study, found that the craniofacial characteristics of subjects with normal and postnormal occlusions became more defined with advancing age. These studies evaluated growing subjects at various ages, but none considered non-growing adults.

Regarding the present results, the significant differences found for sex in Class I malocclusion cases correspond to the sella angle. The behavior of this angle is strongly linked to the behavior of facial height. If the angle is small, the condyle is projected downward and slightly forward reflecting an increase in posterior and anterior facial height. This same characteristic was also observed for facial height on the skeletal Class III group. This result is consistent with the findings by Baccetti et $\mathrm{al}^{29}$ who studied a population between 3 and 57 years old. They found that Class III malocclusion is associated with a significant degree of sexual dimorphism in craniofacial parameters, especially from the age of 13 onward. In women, the sella angle turned out to be broader than in men, causing backward projection of the condyle and generating a slightly retrognathic profile reflected in the associated convex facial pattern. This sex characteristic was also reported by Pecora et al. ${ }^{21}$ The significant differences found in our study according to sex in Class III patients on the articular angle level do not coincide with the findings by Baccetti et a ${ }^{29}$ who found no sex differences at this angle, the so-called "cranial bending angle", neither sex differences in Class II. This result is consistent with findings by Chung and Wong ${ }^{30}$ who studied Class II growing patients and found that skeletal changes in angular measurements were similar in male and female groups. However, linear measurements showed significant differences. Our results suggest that the behavior of the saddle angle affects facial height, and it is also reflected in the dentofacial skeletal pattern.
In our study, the facial growth pattern of Class III patients was strongly differentiated from other skeletal classes. There were significant differences found in the gonial and superior gonial angles on Class III subjects compared with Class I and II subjects. The development of Class III is multifactorial and complex, being derived from different combinations of dental and skeletal factors, changes in magnitude, direction, and timing of craniofacial growth. The findings of this study indicate a specific characterization of adult Class III subjects in which the behavior of their facial growth tends to be hyperdivergent, derived from the opening of the gonial angle and upper gonial angle and the projection of the symphysis of the chin forward. Other known factors that contribute to this condition are size, position and shape of the maxilla, mandible, skull base, teeth and glenoid fossa.

The sum of the sella, articular, and gonial angles according to Björk is one of the parameters that define the type of growth in a subject. The estimated value is $396 \pm 6^{\circ}$, for an individual with neutral growth. ${ }^{31}$ Variations on this estimate can cause hyper or hypodivergent facial growth tendencies. In our study, the behavior of the polygon sum (Björk) showed no significant differences in relation to the published standard for the three sagittal skeletal classes. This reveals that despite differences between the various angles between skeletal classes, the result of growth was similar in this sample. In addition, an increased angle in one sagittal skeletal class can be compensated with the decrease of another angle on the same group. Saltaji et a ${ }^{132}$ evaluated the association between vertical facial morphology and overjet in untreated Class II subjects. They performed an analysis of the performance criteria of the sum (Björk) and facial proportions, and found a strong relationship between overjet, the sum (Björk), gonial angle and lower gonial angle. Their findings are in agreement with our results. Furthermore, findings such as the behavior of the lower gonial angle in Class III subjects are interesting. This angle has a strong tendency to increase in this sagittal skeletal pattern with respect to the other sagittal skeletal classes. This difference reinforces the vertical and hyperdivergent pattern of this sagittal skeletal class.

Also, similar findings were reported for the sella angle when skeletal Class I and Class III were com- 
pared in men. This angle is also called "angle of the cranial base" and there is no consensus if the articular or the basion point should be used. Proff et $\mathrm{a}^{33}$ found a statistically significant reduction in this angle, with a mean of $17.7 \pm 3.05^{\circ}$ in Class III subjects. Guyer et $\mathrm{al}^{34}$ also reported an acute cranial base angle compared with skeletal Class I subjects in subjects growing up to 15 years. In the present study, there were almost no changes in this angle. No statistically significant differences were found, with skeletal Class III patients reporting the lowest values. The role of the cranial base is still controversial, and some authors argue that the cranial base in skeletal Class III subjects did not differ morphologically from the one in a Class I normal profile. ${ }^{35}$

The present study can shed some additional light on our understanding on how the sum of Björk and Jarabak's polygon behaves in different sagittal skeletal relations. According to the proportion calculation between the posterior facial height (S-Go) and the anterior facial height (N-Me), one subject can be considered hyperdivergent if this ratio is $59 \%$ or less, hypodivergent if it is $65 \%$ or more and neutral if proportion is between 60 to $64 \% .{ }^{13}$ Our sample of Class I male and female adults had an hypodivergent biotype. Class II women had a neutral biotype, while Class II men were hypodivergent. In Class III, there were no sex differences and the facial biotype was neutral. Therefore, in our sample, there was a tendency to develop hypodivergent growth pattern in the three sagittal skeletal classes with a mandibular rotation in counterclockwise direction. According to these findings, the study population can be characterized not only by the three facial biotypes defined by Björk, since almost all of them are classified as hypodivergent or neutral facial growth, and the most extreme vertical cases were classified as neutral. In this regard, the verticality criteria in the facial subject context can be highlighted. Also, this issue is not considered by the ANB in the classic sagittal skeletal classification.

The deep vertical orientation described on Class III subjects was demonstrated with the gonial angles in a downward and backward direction on Björk and Jabarak analysis. This finding may be of paramount importance as it adds clinical information to other studies on Class III patients.

\section{CONCLUSIONS}

Björk and Jabarak cephalometric analysis on CBCT synthesized cephalograms with different dentofacial sagittal skeletal patterns showed a downward and backward direction at the gonial and superior gonial angle on Class III sagittal malocclusion subjects. 


\section{REFERENCES}

1. Cevidanes LH, Heymann G, Cornelis MA, DeClerck HJ, Tulloch C. Superimposition of 3-dimensional cone-beam computed tomography models of growing patients. Am J Orthod Dentofacial Orthop. 2009;136(1):94-9.

2. Cevidanes LH, Figueiredo Oliveira AE, Grauer D, Styner M, Proffit WR.Clinical application of 3D imaging for assessment of treatment outcomes. Semin Orthod. 2011;17(1):72-80

3. Tai K, Hotokezaka H, Hyun Park J, Tai H, Miyajima K, Choi M, et al. Preliminary cone-beam computed tomography study evaluating dental and skeletal changes after treatment with a mandibular Schwartz appliance. Am J Orthod Dentofacial Orthop. 2010;138(3):262.e1-11

4. Ludlow JB, Davies-Ludlow LE, Brooks SL. Dosimetry of two extraoral direct digital imaging devices: NewTom cone beam CT and Orthophos Plus DS panoramic unit. Dentomaxillofac Radiol. 2003:32(4):229-34

5. Farman AG, Scarfe WC. Development of imaging selection criteria and procedures should precede cephalometric assessment with cone-beam computed tomography. Am J Orthod Dentofacial Orthop. 2006;130(2):257-65

6. Farman AG, Scarfe WC.The Basics of maxillofacial cone beam computed tomography. Semin Orthod. 2009:(15):2-13.

7. Huang J, Bumann A, Mah J. Three-dimensional radiographic analysis in orthodontics. J Clin Orthod. 2005;39(7):421-8

8. Deguchi T Sr, Katashiba S, Inami T, Foong KW. Huak CY. Morphologic quantification of the maxilla and the mandible with cone-beam computed tomography. Am J Orthod Dentofacial Orthop. 2010;137(2):218-22.

9. Cattaneo PM, Bloch CB, Calmar D, Hjortshoj M, Melsen B. Comparison between conventional and cone-beam computed tomography-generated cephalograms Am J Orthod Dentofacial Orthop. 2008;134(6):798-802.

10. Moshiri M, Scarfe WC, Hilgers ML, Scheetz JP, Silveira AM, Farman AG. Accuracy of linear measurements from imaging plate and lateral cephalometric images derived from cone-beam computed tomography. Am J Orthod Dentofacia Orthop. 2007:132(4):550-60.

11. Kumar V, Ludlow JB, Mol A, Cevidanes L. Comparison of conventional and cone beam CT synthesized cephalograms. Dentomaxillofac Radiol. 2007:36(5):263-9.

12. Kumar V, Ludlow J, Soares Cevidanes LH, Mol A. In vivo comparison of conventional and cone beam CT synthesized cephalograms. Angle Orthod. 2008:78(5):873-9

13. Jarabak JR, Fizzel JA. Technique and treatment with lightwire appliances. 2a ed. St Louis: CV Mosby; 1972

14. Bjork A. Prediction of mandibular growth rotation. Am J Orthod 1969:55(6):585-99.

15. Burstone CJ, James RB, Legan H, Murphy GA, Norton LA. Cephalometrics for orthognathic surgery. J Oral Surg. 1978;36(4):269-77.

16. Baccetti T, Franchi L, McNamara JA Jr. The cervical vertebral maturation method: some need for clarification. Am J Orthod Dentofacial Orthop. 2003:123(1):19A-20A

17. Northway RO Jr, Alexander RG, Riolo ML. A cephalometric evaluation of the old Milwaukee brace and the modified Milwaukee brace in relation to the normal growing child. Am J Orthod. 1974;65(4):341-63.
18. Oz U, Orhan K. Abe N. Comparison of linear and angular measurements using two-dimensional conventional methods and three-dimensional cone beam CT images reconstructed from a volumetric rendering program in vivo. Dentomaxillofac Radiol. 2011;40(8):492-500

19. Ghoneima A, Albarakati S, Baysal A, Uysal T, Kula K. Measurements from conventional, digital and CT-derived cephalograms: a comparative study. Aust Orthod J. 2012;28(2):232-9.

20. Franchi L, Baccetti T, MCNamara JA Jr. Cephalometric floating norms for North American adults. Angle Orthod. 1998;68(6):497-502.

21. Pecora NG, Baccetti T, McNamara JA Jr. The aging craniofacial complex: a longitudinal cephalometric study from late adolescence to late adulthood. Am J Orthod Dentofacial Orthop. 2008;134(4):496-505.

22. West KS, MCNamara JA Jr. Changes in the craniofacial complex from adolescence to midadulthood: a cephalometric study. Am J Orthod Dentofacial Orthop. 1999:115(5):521-32.

23. Chung $\mathrm{CH}$, Mongiovi VD.Craniofacial growth in untreated skeletal Class I subjects with low, average, and high MP-SN angles: a longitudinal study. Am J Orthod Dentofacial Orthop. 2003;124(6):670-8

24. Alexander AE, MCNamara JA Jr, Franchi L, Baccetti T. Semilongitudinal cephalometric study of craniofacial growth in untreated Class III malocclusion Am J Orthod Dentofacial Orthop. 2009:135(6):700.e1-14; discussion 700-1.

25. Reyes BC, Baccetti T, McNamara JA Jr.An estimate of craniofacial growth in Class III malocclusion. Angle Orthod. 2006;76(4):577-84.

26. Kuramae M, Magnani MB, Boeck EM, Lucato AS. Jarabak 's cephalometric analysis of Brazilian black patients. Braz Dent J. 2007:18(3):258-62.

27. Dibbets JM. Morphological associations between the Angle classes. Eur J Orthod. 1996;18(2):111-8

28. Kerr WJS, Hirst D. Craniofacial characteristics of subjects with normal and postnormal occlusions. Am J Orthod Dentofacial Orthop. 1987:92(3):207-12.

29. Baccetti T, Reyes BC, MCNamara JA Jr. Gender differences in Class II malocclusion. Angle Orthod. 2005:75(4):510-20.

30. Chun-Hsi Chung, Wallace W.Craniofacial growth in untreated skeletal Class II subjects: a longitudinal study. Am J Orthod Dentofacial Orthop 2002:122(6):619-26

31. Bjork A.Variations in the growth pattern of the human mandible: longitudinal radiographic study by the implant method. J Dent Res. 1963:42(1 Pt 2):400-11.

32. Saltaji H, Flores-Mir C, Major PW, Youssef M. The relationship between vertical facial morphology and overjet in untreated Class II subjects. Angle Orthod. 2012:82(3):432-40

33. Proff P, Will F, Bokan I, Fanghanel J, Gedrange T. Cranial base features in skeletal Class III patients. Angle Orthod. 2008;78(3):433-9.

34. Guyer EC, Ellis E III, McNamara JA Jr, Behrents RG. Components of class III malocclusion in juveniles and adolescents. Angle Orthod. 1986;56(1):7-30

35. Anderson D, Popovich F. Relation of cranial base flexure to cranial form and mandibular position. Am J Phys Anthropol. 1983;61(2):181-7. 